\title{
Correction to: Sequence stratigraphy of subsurface upper Eocene-lower Oligocene deposits, Dahomey Basin, southwestern Nigeria: palynological and palynofacies approach
}

\author{
Olayiwola Moshood Adegboyega ${ }^{1}$ - Durugbo Ernest Uzodimma ${ }^{2} \cdot$ Fajemila Olugbenga Temitope $^{3}$. \\ Olaonipekun Moses Oyebanjo ${ }^{1}$ (i)
}

Received: 10 September 2021 / Accepted: 10 September 2021 / Published online: 13 January 2022

(C) Saudi Society for Geosciences 2022

Correction to: Arabian Journal of Geosciences (2021) 14:1420.

https://doi.org/10.1007/s12517-021-07693-0

The original version of this paper was published with error. Figures 4, 5, 6, 7, 8 and Plates 1, 2 were incorrectly assigned to their captions. Given in this article are the correct figures and plates.

The online version of the original article can be found at https://doi.org/ 10.1007/s12517-021-07693-0

Olayiwola Moshood Adegboyega

moshood.adegboyega@gmail.com

Durugbo Ernest Uzodimma

durugboe@run.edu.ng

Fajemila Olugbenga Temitope

olugbenga.fajemila@uniosun.edu.ng

Olaonipekun Moses Oyebanjo

oladayo2004@yahoo.com

1 Natural History Museum, Obafemi Awolowo University,

Ile-Ife, Nigeria

2 Department of Biological Sciences, Redeemer's University, P.M.B.

230, Ede, Nigeria

3 Department of Geological Sciences, Osun State University,

Osogbo, Nigeria 


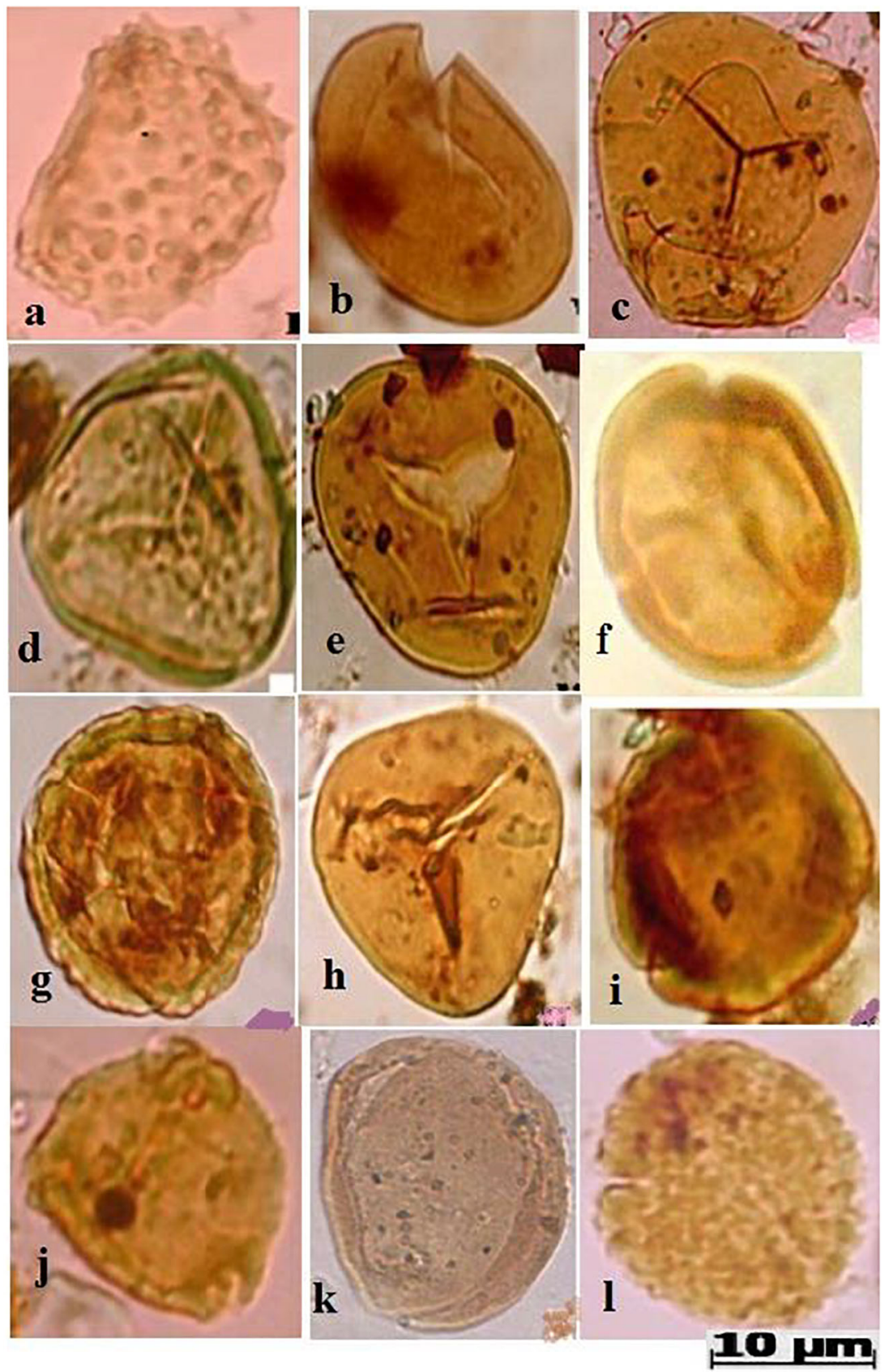

Plate 1 Micrographs of some palynomorphs from the Dahomey Basin. a) Verrucatosporites usmensis Van der Hammen,1954; b) Laevigatosporites sp. Ibrahim 1933; c) Leiotriletes adriennis Potonié et Gelletich, 1933; d) Polypodiaceoisporites retirugatus Muller 1968; e) Deltoidospora adriennis; f) Zonocostites ramonae Germeraad, Hopping and Muller 1968; g) Psilatricolporites crassus Van der Hammen and Wymstra, 1964; h) Proxapertites cursus Van Hoeken-Klinkenberg 1966; i) Retibrevitricolporites ibadanensis j) Retribrevicolporites triangulatus Van Hoeken-Klinkenberg 1966; k) Psilatricolporites operculatus; 1) Racemonocolpites hians Legoux 1978 
Plate 2 Micrographs of some palynomorphs from the Dahomey Basin. a) Retibrevitricolporites obodoensis/protrudens Legoux, 1978; b) Monoporites annulatus, c) Pachydermites diederixi G.H.M 1968, d) Grimsdalea polygonalis Germeraad, Hopping and Muller, 1968, e)

Achomosphaera alcicornu

Eisenack,1954, and Davey and

Williams, 1966, f)

Adnatosphaeridium

multipinosum Williams and

Downie, 1966, g) Homotryblium

plectilum Drugg and Loeblich Jr.

1967, h) Homotryblium

abbreviatum Eaton1976, i)

Selenopemphix nephroides Benedek, 1972, j) Leiosphaeridia sp., k) Glaphyrocysta semiteca Bujak, 1980, and Lentin and Williams, 1981, 1) Apectodinium. sp.
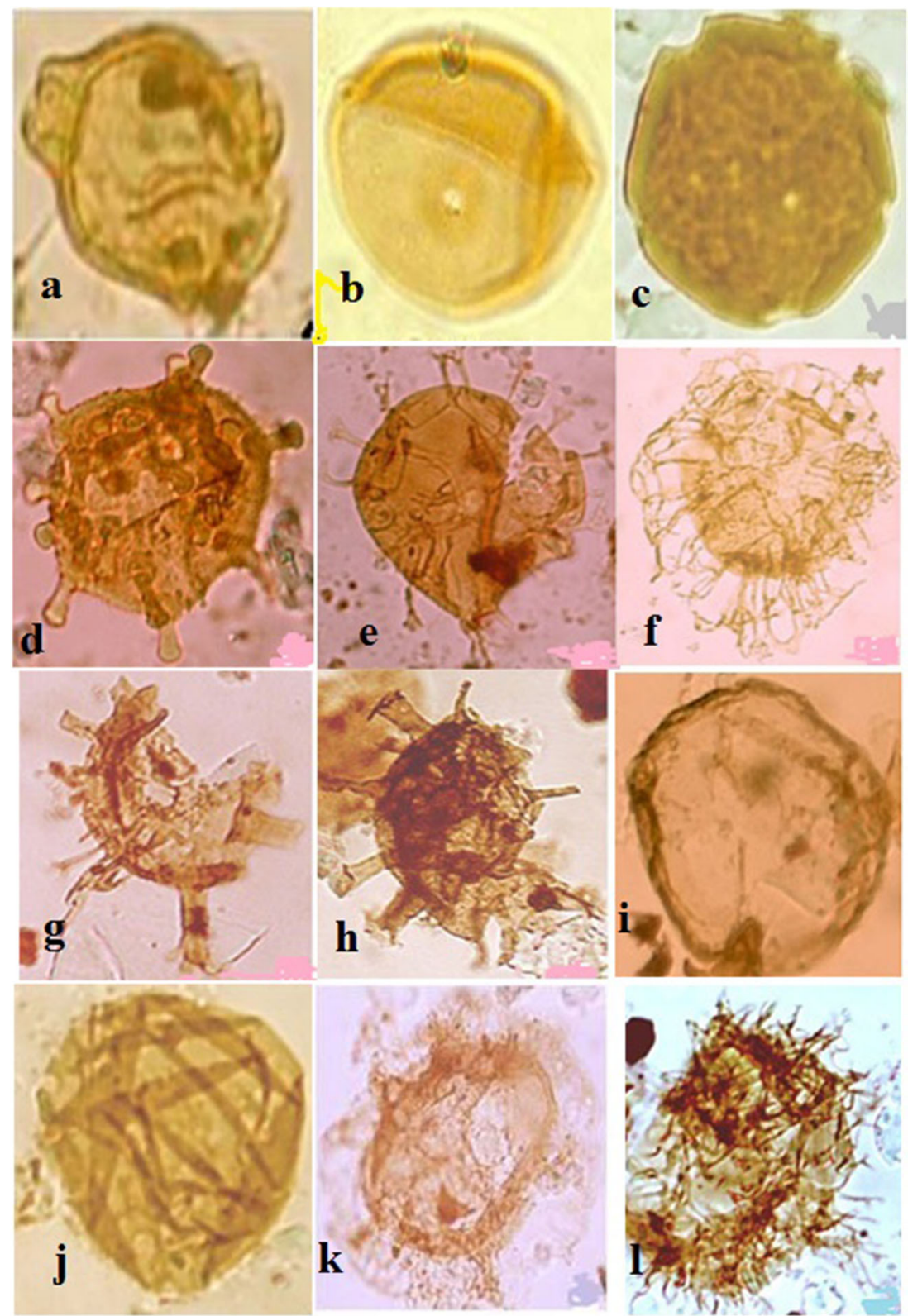

$10 \mathrm{im}$ 
(A) Olokonla Borehole

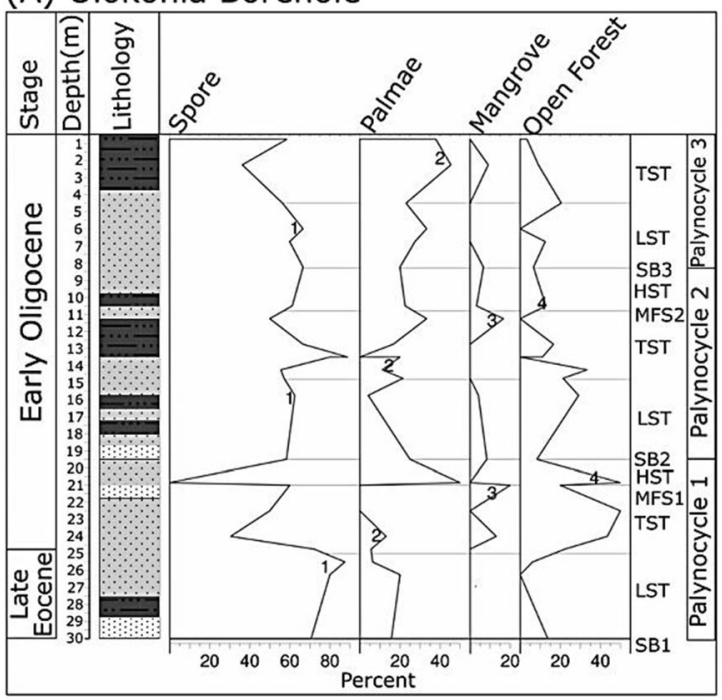

(C) Epe Borehole
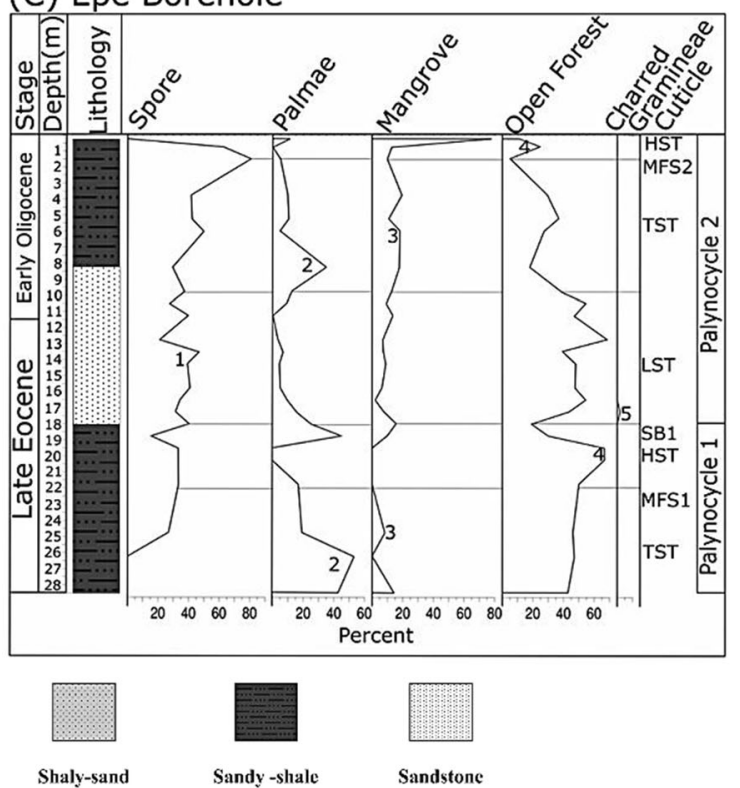

(B) Badore Borehole

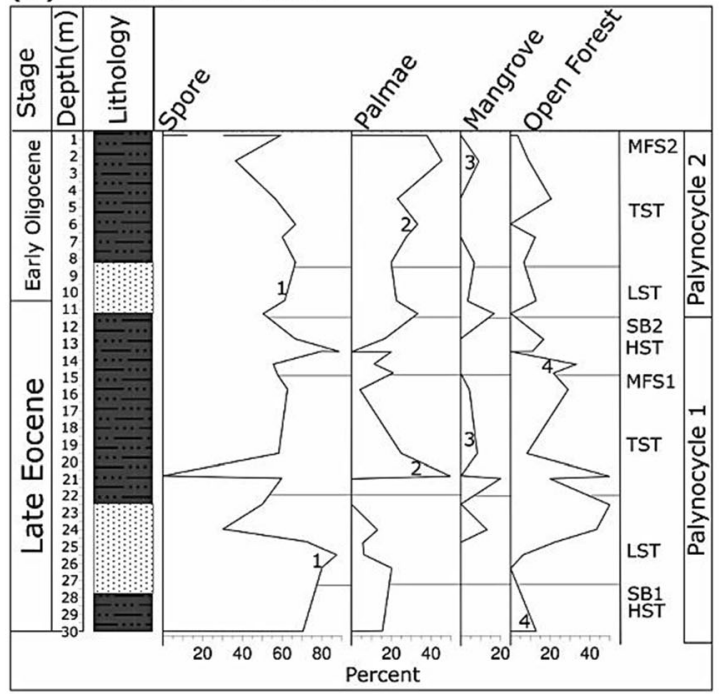

(D) Ikoyi Borehole

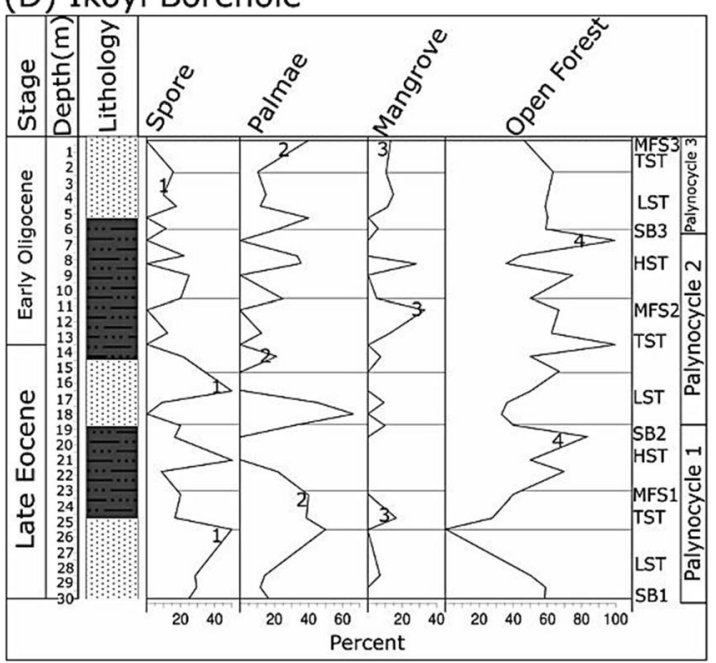

Fig. 5 Charts of ecological groups (Spores, Palmae, Mangrove, Open Forest and Charred Gramineae Cuticle) and their sequence stratigraphic interpretation for the boreholes of Dahomey Basin a) Olokonla-1, b) Badore-1, c) Epe-1 and d) Ikoyi-1 
(A) Olokonla Borehole

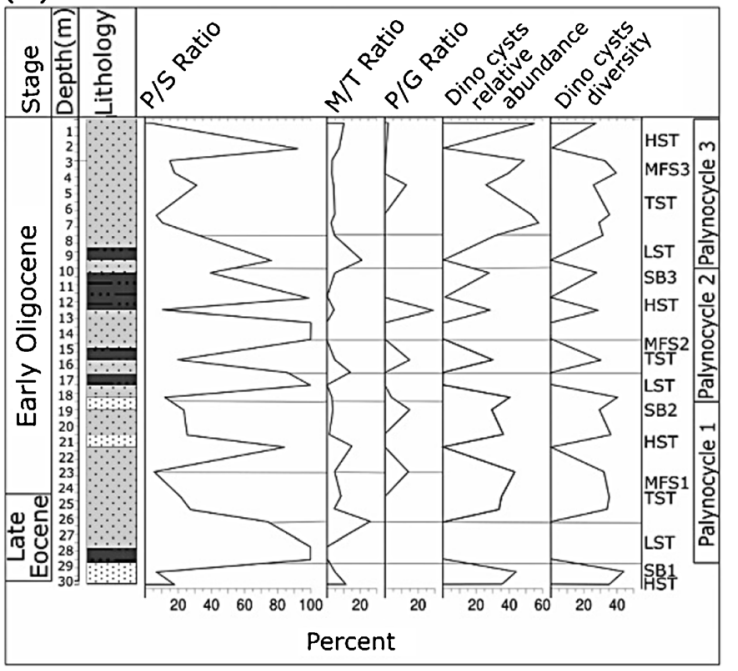

(C) Epe Borehole
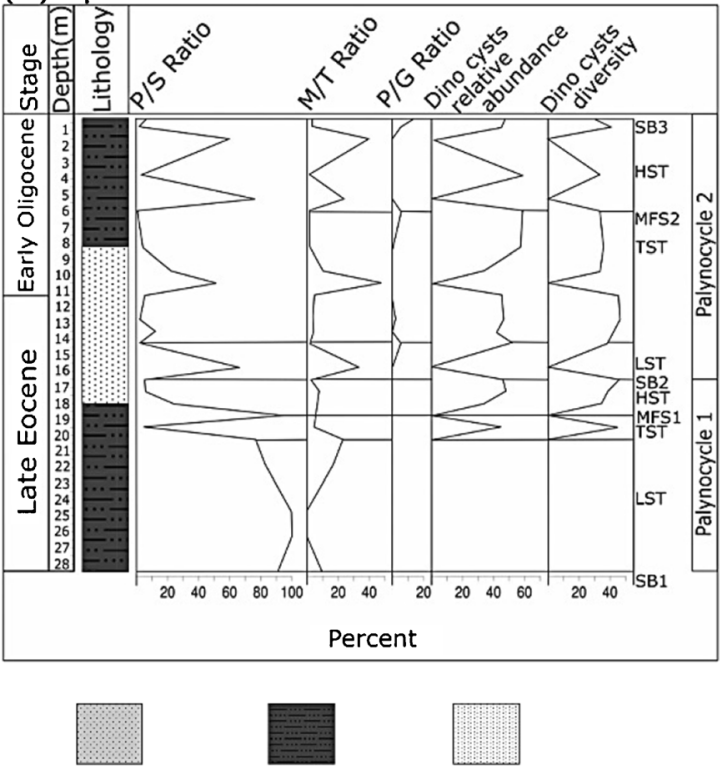

Shaly-sand

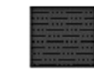

Sandy -shale

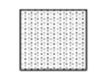

Sandstone

Fig. 6 Charts of $\mathrm{P} / \mathrm{S}$ ratio, $\mathrm{M} / \mathrm{T}$ ratio, $\mathrm{P} / \mathrm{G}$ ) ratio, dinocysts abundance and diversity, and their sequence stratigraphic interpretation for the boreholes of

Dahomey Basin; a) Olokonla-1, b) Badore-1, c) Epe-1 and d) Ikoyi-1
(B) Badore Borehole

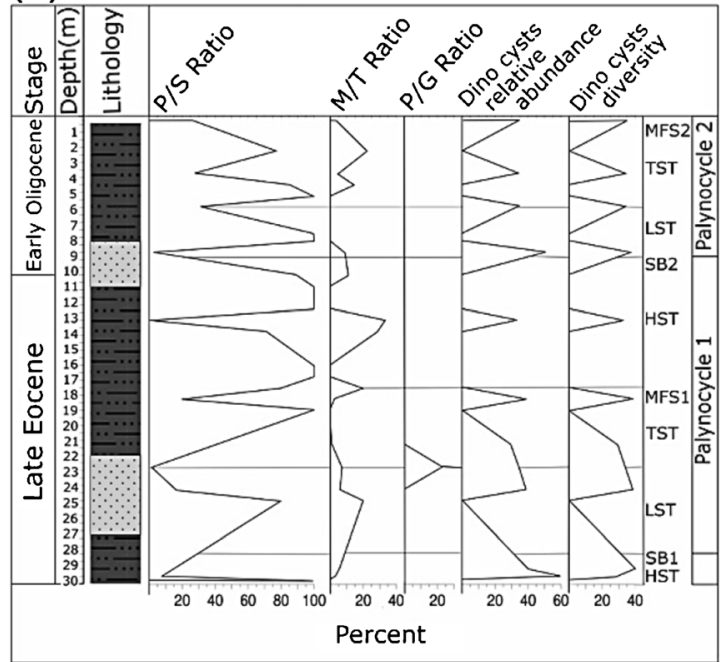

(D) Ikoyi Borehole

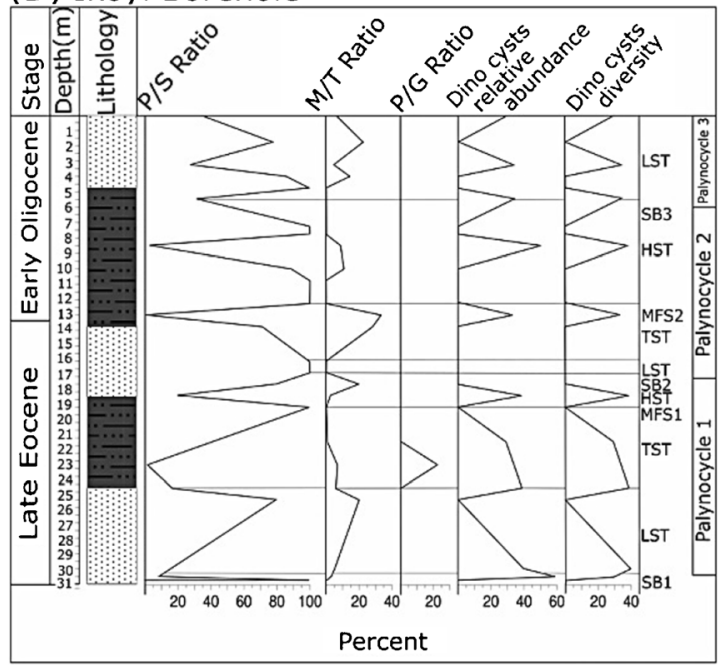


(A) Olokonla Borehole

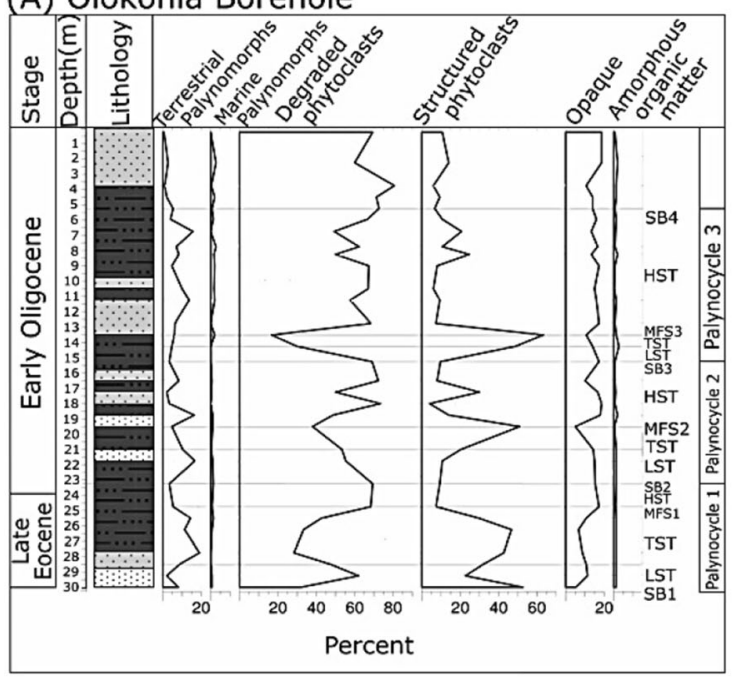

(C) Epe Borehole

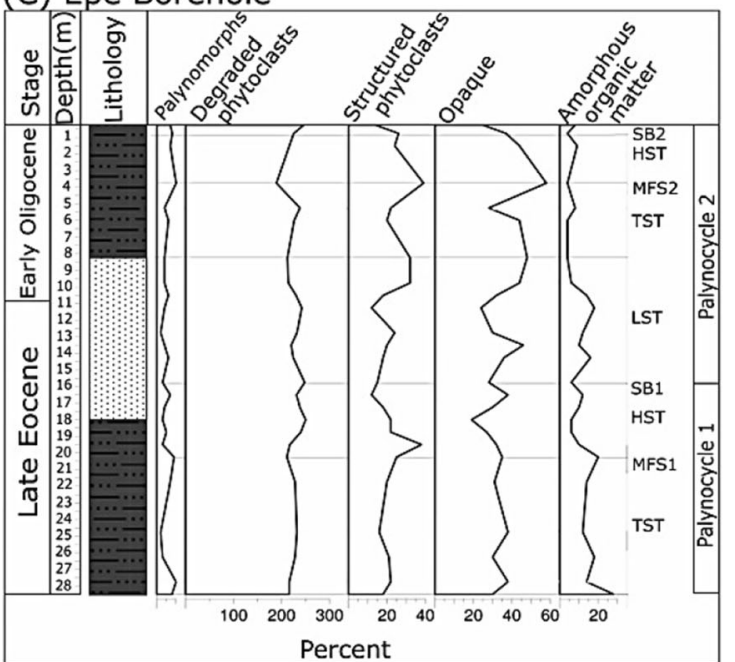

Percent
(B) Badore Borehole

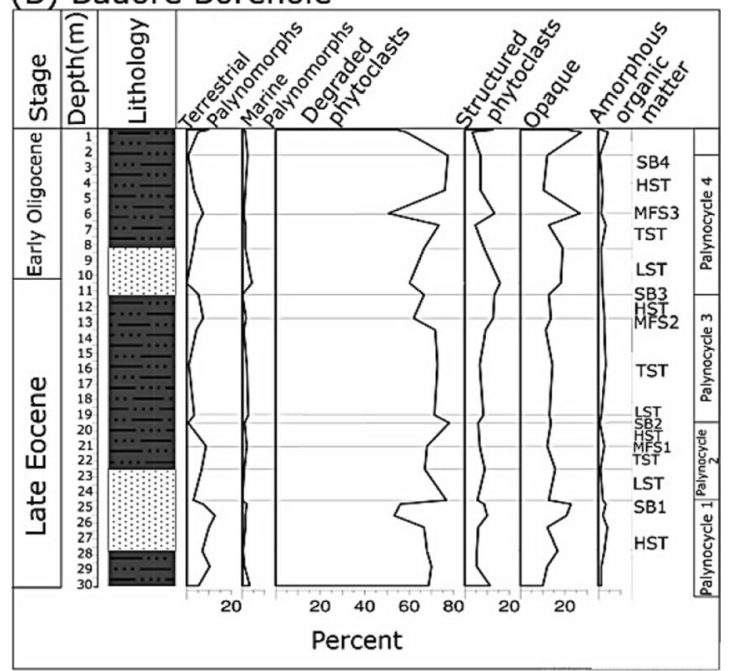

(D) Ikoyi Borehole

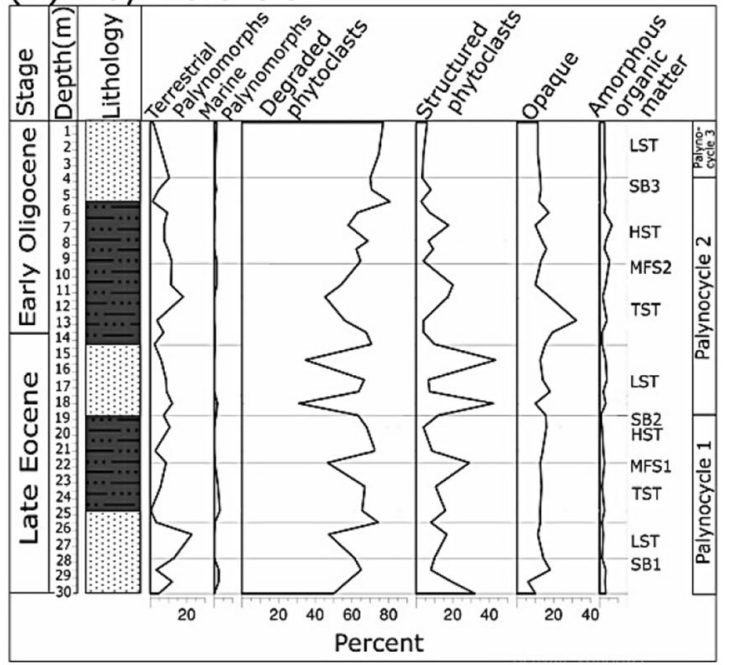

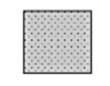
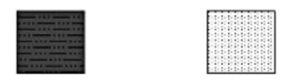

Shaly-sand

Sandy -shale

Sandstone

Fig. 7 Chart of palynofacies groups (AOM, phytoclasts and palynomorphs) and their sequence stratigraphic interpretation for theboreholes of Dahomey Basin; a) Olokonla-1, b) Badore-1, c) Epe-1 and d) Ikoyi-1 
Fig. 8 Maximum Flooding

Surfaces diagram of the boreholes

of Dahomey Basin

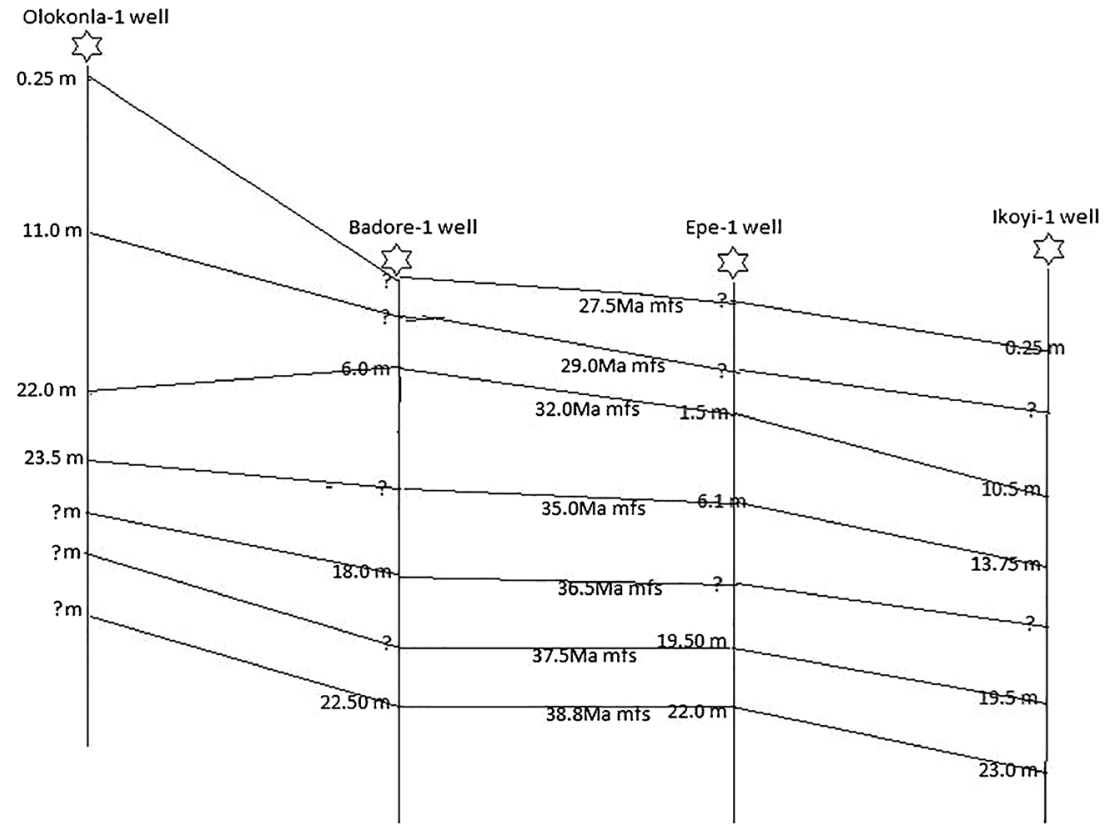

